\title{
アークエネルギーによる磁性超微粒子生成法の研究
}

\section{A Study of a Generation Process of Magnetic Ultra Fine Particles with Arc Energy}

\author{
遠藤 喜 重 ${ }^{*}$, 茨木 善 朗 ${ }^{* *}$, 金丸 昌 敏 ${ }^{*}$, \\ Yoshishige ENDO, Yoshirou IBARAKI, Masatoshi KANAMARU, \\ 荒谷雄 ${ }^{* *}$, 日 置 進* \\ Takeshi ARAYA, Susumu HIOKI
}

\begin{abstract}
A generating process of magnetic ultra fine particles (UFPs) was studied using an arc discharge method combined with a tilted electrode assembly.

The arc was generated between a tungsten electrode cathode and a bulk material anode in an argonhydrogen gas atmosphere. $\mathrm{Fe}$-Co alloy was used as the bulk material. The results obtained are as follows:

(1) In the region where the hydrogen content was below $70 \%$ in volume, the generation rate increased as the hydrogen content increased, however in the region where the hydrogen content was at $100 \%$, the rate decreased slightly.

(2) The mean diameters of the UFPs were below $40 \mathrm{~nm}$ and the UFPs formed chain like agglomerates at $30 \%$ and $100 \%$ hydrogen contents. On the other hand, in $50 \%$ and $70 \%$ content, the mean diameters were over $90 \mathrm{~nm}$ and up to $200 \mathrm{~nm}$ particles were formed.

(3) The coercive force Hc of UFPs were nearly $110 \mathrm{kA} / \mathrm{m}$ at $30 \%$ and $100 \%$ hydrogen content, which is twice of those at $50 \%$ and $70 \%$ contents.
\end{abstract}

Key Words : Ultra Fine Particles, Arc Energy, Magnetic Particles, Fe-Co Alloy.

\section{1. 緒言}

前報1.2) までに，アークエネルギーを利用した金属 及び金属酸化物超微粒子の生成法について, アーク現 象の観点から検討を行い, 超微粒子原材料と対向する 電極の角度を 45 度近傍に設定すると（以下斜向電極 法之称す), 超微粒子の生成量が大幅に増加すること を明らかにした。また，二元合金酸化物超微粒子を生 成する場合には，母材の混合組成と生成した超微粒子 の組成とが異なるが, あらかじめ母材の組成比を变え ておけば所望組成比の超微粒子が得られることを明ら かにした。

一方磁性超微粒子の研究は, 物性物理学的興味及び

1998年 9 月 11 日受付

* (侏日立製作所 機械研究所

（テ300-0013 茨城県土浦市神立町502）TEL 0298-32-8234

Mechanical Engineering Research Laboratory,

Hitachi Ltd.,

(502 Kandatsu, Tsuchiura-shi, Ibaraki 300-0013)

$* *$ 元日立製作所
磁気記録という工業的な応用の面から，古くから主に 蒸発法を中心に進められてきだ.4)。磁性超微粒子を 工業的に応用する利点は, 保磁力が大きく, 高密度記 録ができ，またその耐候性が優れている点にある。し かし蒸発法で生成した超微粒子はコスト的に割高であ り, 現状では磁気テープ等への工業的応用は主に化学 的方法によって行われている。しかし化学的方法で生 成できる材質は主に酸化鉄系の材料であり, 合金の磁 性超微粒子はその生成が困難であると言われている。

そこで本報では，超微粒子の生成量が従来方法と比 較して大幅に増加する斜向電極法を用いて, 化学的製 法では生成が困難な Fe-Co 系磁性超微粒子生成法の 検討を行った。

\section{2. 実験装置及び実験方法}

\section{1 超微粒子製造装置}

本研究では使用した超微粒子製造装置は，前報と同 様の装置を用いた。装置の概略を Fig. 1 に示す。装置 は超微粒子発生室, 捕集部, 電源部, 真空排気系及び 


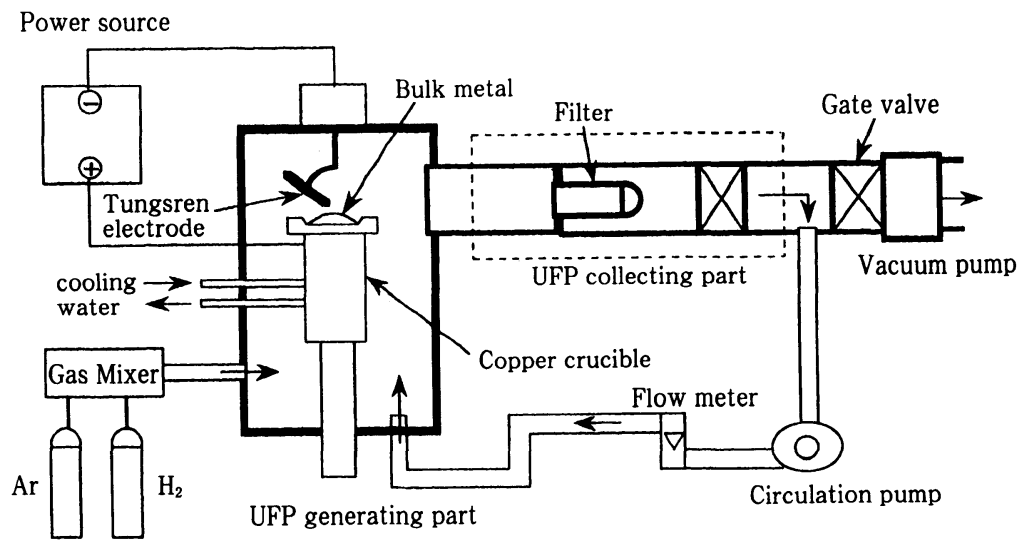

Fig. 1 A sketch of UFPs (Ultra Fine Particles) production apparatus

Table 1 Chemical composition of base metal (wt \%)

\begin{tabular}{ccccc}
\hline Fe & Co & C & Si & Mn \\
\hline 45.42 & 49.64 & 0.026 & 0.15 & 0.12 \\
\hline
\end{tabular}

制御部から構成されている。本装置による超微粒子の 生成方法は，まず水冷銅ルツボ上に超微粒子原材料 （以下母材と略す）を置き, 次に装置内を $10 \mathrm{~Pa}$ 程度 に排気し，所定のガスを約 $0.1 \mathrm{MPa}$ まで封入する。そ の後装置内のガスを循環ポンプにより循環させ, タン グステン電極を陰極，母材を陽極として両電極間に アークを発生させ，このアーク熱により母材を溶融 させて超微粒子を生成する。生成した超微粒子は, 循環ガスによって捕集部に搬送されて繊維質フィル ターに捕集される。母材は $\mathrm{Fe}-\mathrm{Co}$ 系合金を用いた。

Table 1 にこの母材の化学組成を示す。またアーク電 流は 200A一定とした。

\section{2 超微粒子生成量の測定}

超微粒子生成量は, 実験前と実験後の母材重量を測 定して，その減少量を 1 時間当たりに換算 $(\mathrm{g} / \mathrm{h}) し$ て求めた。捕集部の䄉維質フィルターでの回収率は, 母材重量減から求めた生成量の約 $60 \%$ である。

\section{3 磁気特性の測定}

磁気特性はVSM (Vibrating Sample Magnetmeter）を用いてヒステリシス曲線を測定しこの曲 線から保磁力 $H_{\mathrm{c}}$ を求めた。

\section{4 平均粒径及び粒度分布の測定}

生成した超微粒子は, 透過型電子顕微鏡 (TEM) に より写真撮影し, この写真から画像解析装置を用いて 平均粒径を測定した。具体的には, 画像解析装置によ りまず粒子一つ一つを自動及び手動で分離し, その後

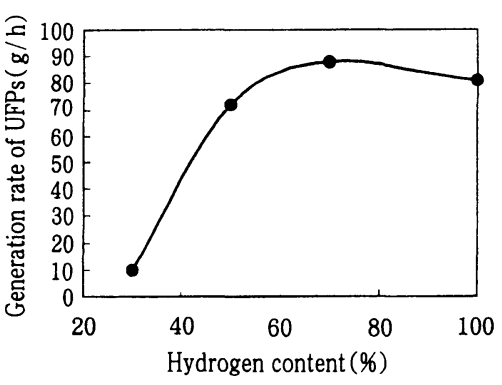

Arc current ; 200A, Electrode angle ; $45^{\circ}$

Fig. 2 Influence of hydrogen content on UFPs generation rate

それらの面積と個数を求め, $N=200 \sim 500$ の総面積 を個数で割った值を平均粒径とした。

\section{3. 実験結果及び結果の検討}

雾囲気ガス中の水素濃度, 電極角度, 循環ガスの冷 却が, 超微粒子生成量及び生成された超微粒子の諸特 性に及ぼす影響について検討を行った。実験は, 約 $50 \mathrm{~g}$ の母材を用いて約 10 分間超微粒子を発生させ た。

最も多い生成量は, 後述するように $85 \mathrm{~g} / \mathrm{h}$ 程度で あるから，この場合母材は $28 \%$ 減少したことにな る。この程度の減少では母材の形状はほとんど変化せ ず, アークの発生状態も変化しないことを確認してい る。したがって発生量及び生成した超微粒子の形状の 時間的変化はほとんどないものと推察される。

3. 1 水素濃度の影響

Fig. 2 は，超微粒子生成量に及ぼす雾囲気ガス中の 水素濃度の影響を示す。図から明らかなように, 水素 濃度 $70 \%$ までは水素濃度の増加に伴って生成量は増 


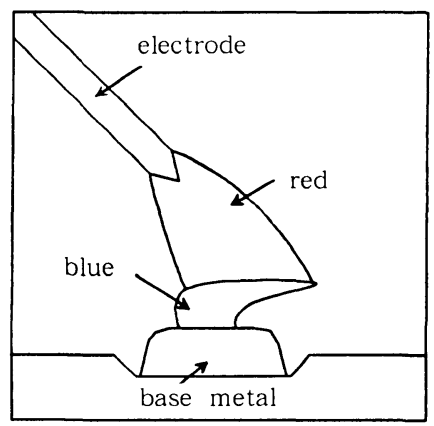

(a) $\mathrm{Ar}+30 \% \mathrm{H}_{2}(32 \mathrm{~V})$

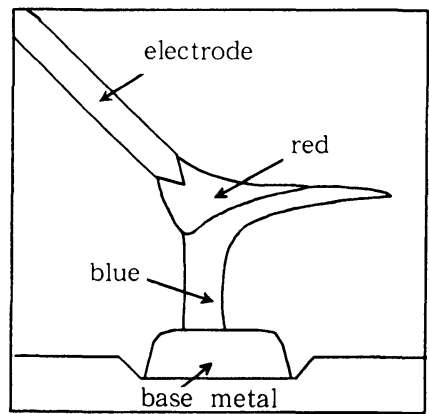

(c) $\mathrm{Ar}+70 \% \mathrm{H}_{2}(38 \mathrm{~V})$

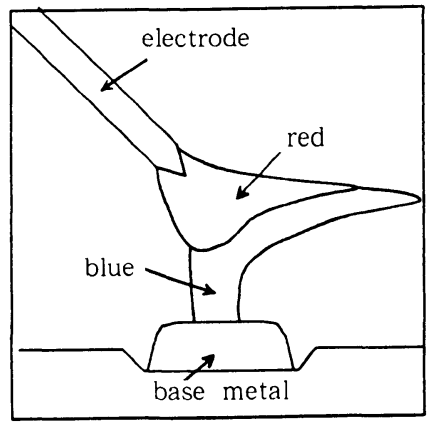

(b) $\mathrm{Ar}+50 \% \mathrm{H}_{2}(35 \mathrm{~V})$

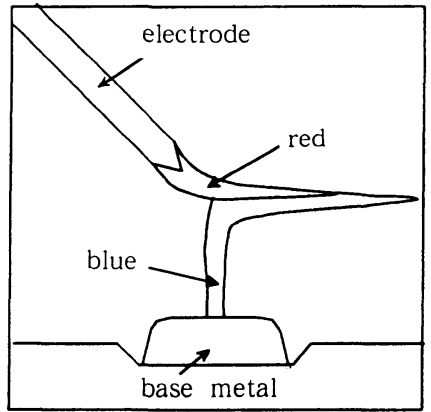

(d) $100 \% \mathrm{H}_{2}(62 \mathrm{~V})$

Fig. 3 Relation between hydrogen content and arc shapes

加している。しかし水素濃度 $100 \%$ では, $70 \%$ と比 較すると減少している。この傾向はこれまで得られた ニッケル超微粒子での結果とほぼ一致している ${ }^{1}$ 。

雲囲気ガス中の水素濃度が増加すると, 水素ガスの 熱解離によるサーマルピンチカによってアークはより 収縮するようになる。また解離した水素ガスは，比較 的温度の低い母材に接触すると熱放出して再合するも のと考えられる ${ }^{5)}$ 。以上のことから，母材表面により 高い高温部が形成されて, 超微粒子生成量が增加す るものと考える。一方, 水素濃度が $100 \%$ の場合に は, 他の条件と異なり特異なアーク形態が観察され た。Fig. 3 は，電極先端と母材との距離を $5 \sim 6 \mathrm{~mm}$ に 設定した場合の，水素濃度を変化させた場合のアーク 形状の観察結果を示す。図中にはアーク電圧も付記 した。図から水素濃度 $100 \%$ では, 水素アーク特有 の赤色のアークが母材にほぼ平行に細長く電極から

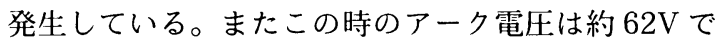
あり, 水素濃度 $50 \%$ 及び $70 \%$ の 35 40V と比較す ると急激に高くなっている。このことから水素濃度 $100 \%$ の場合には, 二原子ガスの $\mathrm{H}_{2}$ がアーク熱によ ってHの原子状に解離する。したがってアーク柱での
熱損失は格段に大きくなる。この時のアークの自己保 持作用，すなわちアーク自身が維持し続けようとする 作用が働き，アークは収縮する。このような状態で,

電極を傾けたことによって生じる電磁力がアークに作 用すると，磁気吹き現象が顕著になるものと考えられ る。

したがって，アーク熱が超微粒子生成に有効に使わ れず，そのため生成量が減少するものと推察される。 また Table 2 は, 生成された超微粒子の磁気特性と化 学組成の測定結果を示す。Table 1 の母材化学組成と 比較すると, $\mathrm{Fe}$ は母材よりも増加, $\mathrm{Co}$ は減少して いる。また Mn は母材と比較すると增加している。 この原因としては, $\mathrm{Mn}$ は $\mathrm{Fe}$ 中に固溶されるために $\mathrm{Fe}$ の増加に伴って増えたと考えられる。一般に $\mathrm{Si}$ 及 びMnは，鉄鋼材料の脱酸剂として用いられてい る。いずれも強磁性材料ではないので，磁気特性には 影響を及ぼさないと考えられる。

保磁力 $H_{\mathrm{c}}$ は水素濃度 $30 \%$ で生成した超微粒子が $111 \mathrm{KA} / \mathrm{m}, 100 \%$ 水素濃度が $113 \mathrm{KA} / \mathrm{m}$ であり, $50 \%$ 及び $70 \%$ 水素濃度の超微粒子と比較すると 2 倍程度大きい。この原因としては, 超微粒子の粒径及 
Table 2 Chemical composition (wt\%) and magnetic characteristic of ultra-fine particles

\begin{tabular}{rcccc}
\hline $\mathrm{H}_{2}(\%)$ & $\mathrm{Fe}$ & $\mathrm{Co}$ & $\mathrm{Mn}$ & Hc $(\mathrm{KA} / \mathrm{m})$ \\
\hline 30 & 53.84 & 44.26 & 1.90 & 111.4 \\
50 & 56.99 & 42.78 & 0.53 & 44.5 \\
70 & 55.11 & 44.40 & 0.48 & 56.2 \\
100 & 53.85 & 45.99 & 0.16 & 113.0 \\
\hline
\end{tabular}

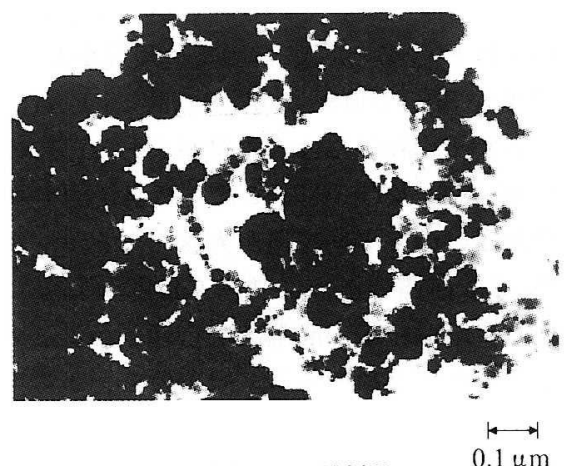

(1) $\mathrm{Ar}+50 \% \mathrm{H}_{2}$

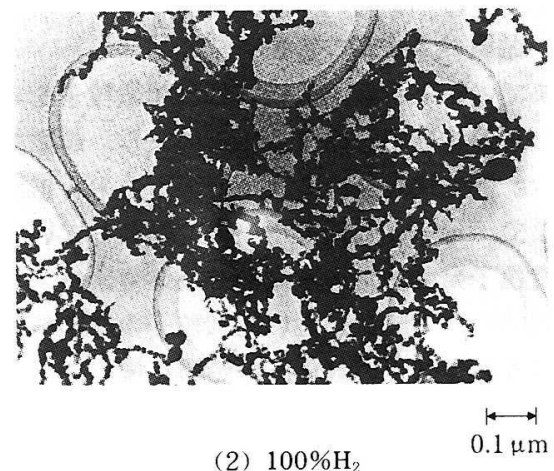

Arc current; $200 \mathrm{~A}$, Electrode angle ; $45^{\circ}$

Fig. 4 TEM photographs of UFPs

び形状の違いが考えられる。

Fig. 4 はこの超微粒子の TEM 写真の一例として, 水素濃度 $50 \%$ と $100 \%$ の超微粒子を示す。水素濃度 $50 \%$ では, 粒径が $200 \mathrm{~nm}$ 以上の巨大化した微粒子 が数多く混在していることが分かる。一方, 水素濃度 $100 \%$ では, 粒径が $100 \mathrm{~nm}$ 以下の超微粒子が鎖状に 連なっている。

Fig. 5 は，画像解析装置を用いて測定した平均粒径 と水素濃度との関係を示す。水素濃度 $30 \%$ 及び 100 $\%$ の超微粒子の平均粒径が $40 \mathrm{~nm}$ 以下であるのに対 して, 水素濃度 $50 \%$ 及び $70 \%$ の超微粒子は $90 \mathrm{~nm}$

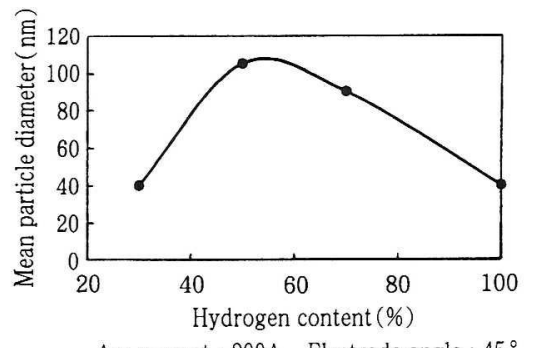

Arc current ; 200A, Electrode angle ; $45^{\circ}$

Fig. 5 Influence of hydrogen content on mean particle diameter of UFPs

\section{以上である。}

このように水素濃度によって生成された超微粒子の 粒径が異なる原因としては以下のことが考えられる。

水素濃度 $30 \%$ ではFig. 2 に示したように, 生成量 が他の条件と比べると格段に少ないので, 生成された 超微粒子同土が接触する機会が少なく, その結果比較 的小さな超微粒子が得られる。これに対して水素濃度 $50 \%$ 及び $70 \%$ では生成量が多いので, 高温状態の 超微粒子同士がお互いに接触して再溶融が起こり, 巨 大化した超微粒子が数多く形成される。一方, 水素濃 度 $100 \%$ ではFig. 3に示すように，そのアーク形態 が他の条件と大きく異なっており, 水素アーク特有の アークが母材とほぼ平行に細長く電極から発生してい る。水素ガス $100 \%$ ではサーマルピンチ効果によ りアアークがより収縮するために高温部の領域が狭く なっている。また磁気吹き現象も顕著になるために, 発生した超微粒子は素早く高温部から遠ざかる。した がって再溶融する機会が少なく, 一次粒径の小さな超 微粒子が生成されたものと推察される。

一般に強磁性体である $\mathrm{Fe}-\mathrm{Co}$ 系合金は，通常のバ ルク体では多磁区構造をしている。この磁区と磁区と の間は磁壁により区切られており,この磁壁の厚みは 約 $100 \mathrm{~nm}$ 之見積られている。微粒子の粒径がこの磁 壁の厚みよりも小さくなると単磁区構造となり, 磁化 の反転はスピンの一斉回転によるものとなりその保磁 
Table 3 Generation rate of UFPs and mean particle diameter on various conditions

\begin{tabular}{ccccc}
\hline $\begin{array}{c}\text { Hydrogen } \\
\text { content }(\%)\end{array}$ & $\begin{array}{c}\text { Electrode } \\
\text { angle }\end{array}$ & $\begin{array}{c}\text { Carrier } \\
\text { gas }\end{array}$ & $\begin{array}{c}\text { Generation } \\
\text { rate }(\mathrm{g} / \mathrm{h})\end{array}$ & $\begin{array}{c}\text { Mean particle } \\
\text { diameter }(\mathrm{nm})\end{array}$ \\
\hline 50 & $75^{\circ}$ & Without & 11 & 44 \\
50 & $45^{\circ}$ & Without & 72 & 106 \\
50 & $45^{\circ}$ & Use & 75 & 74 \\
\hline
\end{tabular}

力に顕著な変化が現れる。また鎖状に連なると, 形状 異方性による効果によって特性が向上すると考えられ ている ${ }^{6)}$ 。

以上のことから, 粒径が $100 \mathrm{~nm}$ 以下で鎖状の形態 をした水素濃度 $30 \%$ 及び $100 \%$ の超微粒子は，より 大きな保磁力を示したものと考えられる。また化学組 成は, 水素濃度 $100 \%$ の超微粒子が最も母材の組成 に近い。

また水素濃度による化学組成の変化は, 例えば Fe の場合水素濃度 $30 \%$ 及び $100 \%$ が $53.8 \%$, 水素濃 度 $50 \%$ 及び $70 \%$ が 55〜 $57 \%$ であり，その傾向は 認められないことからほとんど影響がないものと考え られる。

\section{2 電極角度の影響}

電極角度 $\theta=75^{\circ}$ と $\theta=45^{\circ}$ における, 超微粒子 の生成量及びその粒径を Table 3 に示す。この時の水 素濃度は $\mathrm{Ar}+50 \% \mathrm{H}_{2}$ とした。 $\theta=75^{\circ}$ と $\theta=45^{\circ}$ における超微粒子の生成量を比較すると, 約 7 倍であ る。前報")で明らかにした， $\mathrm{Fe}$ 及び $\mathrm{Co}$ それぞれの $\theta=75^{\circ}$ と $\theta=45^{\circ}$ との生成量を比較すると, $\mathrm{Fe}$ が 約 14 倍, Co が約 2.5 倍である。ここから Table 1 の 組成，すなわち $\mathrm{Fe} ; 45.4 \% ， \mathrm{Co} ; 49.6 \%$ の重みづけ をして算出すると 7.5 倍となり，今回得られた結果は この値とほぼ等しい。

一般にアークプラズマを発生させた場合には，プラ ズマ中心部の温度は $10,000 \mathrm{~K}$ 近くになると考えられ ている。したがってその直下に置かれた母材の表面で は，局部的に数千度の高温に達していると考えられ る。このような高温下は $\mathrm{Fe}$ と Co は原子状に電離し ており，お互いに影響を与えずに蒸発するものと推察 される。したがって単独で得られた生成量を組成比で 重みづけして算出した生成量と, $\mathrm{Fe}$ - Co 合金の生成 量とがほぼ等しくなるものと考えられる。

また異なる条件でほぼ生成量が等しい， $\theta=75^{\circ}$ と Fig. 5 の水素濃度 $30 \%$ とのデー夕を比較すると， $\theta=75^{\circ}$ では生成量が $10 \mathrm{~g} / \mathrm{h}$ で平均粒径が $44 \mathrm{~nm}$, 水素濃度 $30 \%$ では生成量が $10 \mathrm{~g} / \mathrm{h}$ で平均粒径が 40 $\mathrm{nm}$ であり, ほぼ一致している。しかし生成量の多い 条件, 例えばFig. 2 と Fig. 5 の電極角度が $\theta=45^{\circ}$ で水素濃度が 50〜100\% の場合には, 生成量はほぼ 同じであるが平均粒径には大きな差がある。この場合 水素濃度が $50 \%$ 及び $70 \%$ では, 高温状態で再溶融 する機会が多いので平均粒径が大きくなるが, 水素濃 度 $100 \%$ では前述のようにアーク形態が異なり, 素 早く生成した超微粒子が高温部から遠ざかるため平均 粒径が小さくなるためである。以上のことから生成量 と粒径の関係は, 生成量が少ない場合には生成条件の 影響は受けずにその相関はあるが, 生成量の多い場合 には生成条件特にアーク形態に大きく影響される。

\section{3 循環ガス冷却の影響}

これまでの結果から，生成された超微粒子を素早く 高温部から遠ざけて急冷することにより, 超微粒子同 士の結合，巨大化を防ぐことができるものと推察され る。そこで, Fig. 1の循環ポンプで循環しているガス を, 超微粒子発生室に入る直前で液体窒素により冷却 すると同時に, アークに近い超微粒子の通路にこの冷 却されたガスを吹き付けてその影響を検討した。

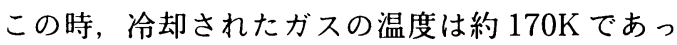
た。この場合の生成量及び平均粒径を Table 3 に示 す。生成量は $75 \mathrm{~g} / \mathrm{h}$ であり，ガスを冷却しない場合 の $72 \mathrm{~g} / \mathrm{h}$ とほぼ等しい。これはアークにガスを直接 吹き付けていないので，アーク形状そのものが変化し ないためと考えられる。一方，平均粒径は $74 \mathrm{~nm} て ゙$ あり, 冷却しない場合の $106 \mathrm{~nm}$ と比較するとかなり 細粒化されている。また $200 \mathrm{~nm}$ 以上の巨大化した超 微粒子は認められなかった。以上の結果から, 循環ガ スを冷却する方法は細粒化のための有効な手段の一つ と考えられる。

\section{4. 結言}

アーク熱源を利用して, $\mathrm{Fe}-\mathrm{Co}$ 系磁性超微粒子を 生成する方法について検討を行い，以下のことを明ら かにした。

（1）生成量は水素濃度 $70 \%$ までは水素濃度が増加す 
るにしたがって増加するが， 100 \% では減少する 傾向にある。

（2）水素濃度 $30 \%$ と $100 \%$ ではその平均粒径は 40 $\mathrm{nm}$ 以下であり，鎖状に連なった状態となる。しか し $50 \%$ 及び $70 \%$ では $90 \mathrm{~nm}$ 以上となり，200nm 以上の巨大化した超微粒子が数多く混在する。

（3）超微粒子の保磁力 $H_{\mathrm{c}}$ は, 水素濃度 $30 \%$ で 111
$\mathrm{KA} / \mathrm{m}, 100 \%$ で $113 \mathrm{KA} / \mathrm{m}$ が得られた。水素濃 度 $50 \%$ 及び $70 \%$ と比較すると， 2 倍程度大きい。 これは細粒化による単磁区構造化と形状異方性によ る効果と考えられる。

（4）循環ガスを液体窒素で冷却して，アークに近い超 微粒子の通路に吹き付けることにより, 平均粒径は 約 $30 \%$ 小さくなる。

\section{Nomenclature}

$N$ : particle numbers

(-) $\quad H_{\mathrm{c}}$ : coercive force

$(\mathrm{KA} / \mathrm{m})$

\section{References}

1) Endo, Y., T. Araya, M. Kanamaru, Y. Ibaraki, R. Okada and S. Hioki: "The Study of a High Efficiency Generation Process of Metallic Ultra Fine Particles with Arc Energy", J. Soc. Powder Technol., Japan, 31, 862-868 (1994)

2 ) Endo, Y., T. Araya, M. Kanamaru, Y. Ibaraki, T. Yamada and S. Hioki: "A study of a Generation Process of Oxide Ultra Fine Particles with Arc Energy", J. Soc. Powder Technol., Japan, 32, 874-880 (1995)
3 ) Kotaibutsuri Tokusyugou : "Choubiryuushi”, Agunu Gijutsu Center (1984)

4 ) Nihon Kagakukai : “Choubiryuusi”, Gakkai Syuppan Center (1985)

5 ) Ando, K. and M. Hasegawa: "Yousetsu Arc Gensyou", Sangyou Syuppan (1970)

6 ) Tasaki, A., S. Tomiyama, S. Iida, N. Wada and R. Uyeda : "Magnetic Properties of Ferromagnetic Metal Fine Particles Prepered by Evaporation in Argon Gas”, Japan J. Appl. Phys., 4, 707 (1965) 